ajfand

\title{
PREVALENCE AND RISK FACTORS OF NUTRITIONAL ANAEMIA AMONG FEMALE SCHOOL CHILDREN IN MASINDI DISTRICT, WESTERN UGANDA
}

\section{Barugahara EI $*^{1,2}$, Kikafunda $\mathrm{J}^{1}$ and WM Gakenia ${ }^{1,3}$}

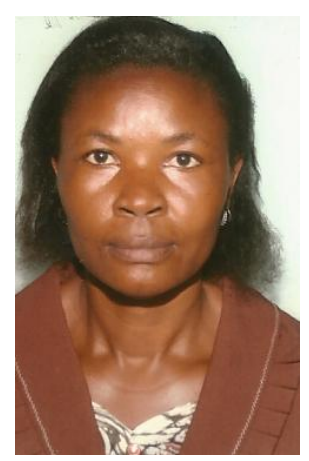

Barugahara Evyline Isingoma

*Corresponding author email: evelyne.isingoma@yahoo.com

${ }^{1}$ Department of Food Science and Technology, Makerere University, P.O.Box 7062, Kampala, Uganda

${ }^{2}$ Department of Human Nutrition and Home Economics, Kyambogo University, P.O. Box 1, Kyambogo

${ }^{3}$ Regional Centre for Quality Health Care, P.O. Box 29140, Kampala, Uganda. 


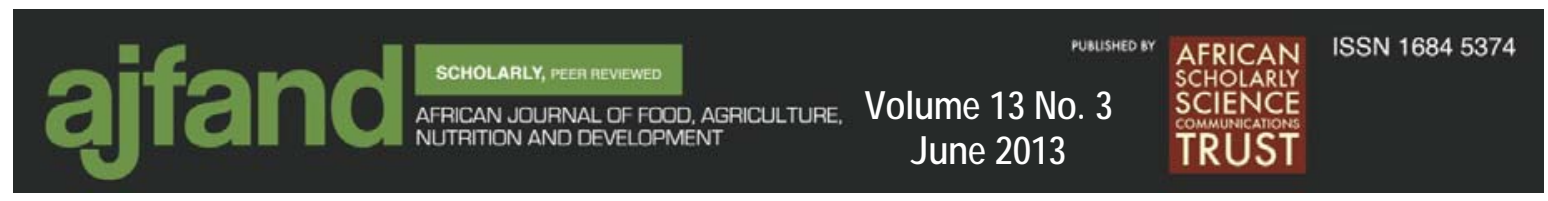

\section{ABSTRACT}

Anaemia is the most widespread nutrition related public health problem world-wide and yet in Uganda, there is little national data on anaemia and its likely causes amongst school children. The aim of this study was to assess the prevalence, dietary and health risk factors of nutritional anaemia amongst 11-14 year old girls attending primary schools in Masindi District of Western Uganda. Two schools, one urban and the other rural, were selected for this cross-sectional study. A total of 109 girls from the upper primary section were randomly selected from both schools. The Lovibond comparator was used to assay Hemoglobin $(\mathrm{Hb})$ level in the whole blood after conversion of $\mathrm{Hb}$ to oxyhemoglobin by ammonia. Pre-tested structured questionnaires were used to collect data. Incidences of malaria were self reported. The dietary intake of iron, protein, folate, riboflavin, energy, vitamin C, dietary fibre and vitamin A was estimated from the East African food composition table used to analyze the 24-hour dietary recalls. Associations between anaemia and factors under investigation were examined using Pearson's chi-square test and Pearson's correlation coefficient analysis. Statistical significance was considered at $\mathrm{p}<0.05$. The overall prevalence of anaemia was $46 \%$. It was twice as high in the urban school (61\%) compared to the rural school (31\%). There was a high intake of plant - based diets; majority of the school children with excess intake of fibre, inadequate intake of iron, protein, folate, riboflavin, energy and vitamin A were anaemic $(\mathrm{p} \leq 0.001)$. Malaria incidences were many and though de-worming was common in schools, it was not consistent. Performance of de-worming by nurses had more impact than that of the teachers. Anaemia was positively correlated with inadequate dietary intake $(\mathrm{r}=0.61, \mathrm{p}<$ $0.001)$, malaria incidences $(r=0.54, \mathrm{p}=0.02)$ and improper de-worming $(\mathrm{r}=0.51, \mathrm{p}$ $=0.04$ ). A high prevalence of anaemia was found amongst the girls, particularly in the urban school. Improper de-worming, malaria incidences and poor feeding were the risk factors of nutritional anaemia. There is, therefore, an urgent need for a national anaemia assessment among this age group and the strengthening of the current School Health Program to address aspects of health and feeding in schools in Masindi district and Uganda as a whole.

Key words: Anaemia, Uganda, Nutrition, School children 


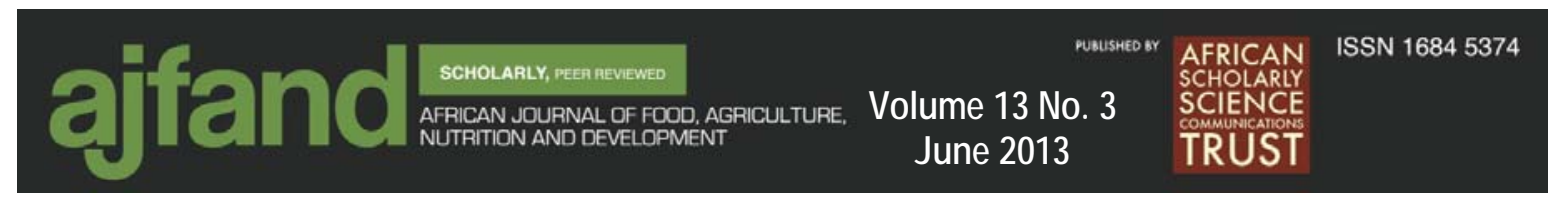

\section{INTRODUCTION}

Anaemia is one of the most widespread forms of malnutrition world-wide and is associated with morbidity, mortality and lost schooling [1, 2]. According to the World Health Organization (WHO) global database, anaemia affects $46 \%$ of school children globally [3]. Africa is one of the most affected regions, with a prevalence rate of $50 \%$ [4]. In Uganda, $43.3 \%$ of adolescent girls aged 15-19 years are anaemic [5]. Data on anaemia prevalence in school children is scanty but the National Rapid Assessment Nutrition Survey in Uganda found anaemia prevalence amongst primary school children in Masindi district to be 7.7\% [6]. Iron deficiency anaemia is responsible for $4.3 \%$ of all deaths and $3.0 \%$ of all hospital admissions in children in Uganda [7]. Iron deficiency anaemia is common whenever diets are low in iron-rich foods especially during periods of rapid growth, bleeding and ill health, being associated with conditions such as malaria and worm infestation [4]. Nutritional anaemia can result from a diet deficient in folate, protein, copper, cobalt, zinc, vitamins A, E, B2, B6, B 12 and ascorbic acid [8,9]. This is because these nutrients are involved in the metabolism of haemoglobin [10]. Complete exclusion of animal foods from meals leads to vitamin $\mathrm{B}_{12}$ deficiency which is likely to result in megaloblastic anaemia, further affecting haemoglobin levels [11]. In Uganda, progress in tackling anaemia in general and nutritional anaemia in particular has been slow despite its reflection in international goals and resolutions as well as various national policies [7]. A survey report of primary schools in 37 districts in Uganda indicated that most day schools lacked organized feeding programs and only a few of these children carried packed lunch to school which was qualitatively and quantitatively inadequate [12]. For boarding schools, there are often complaints of monotony of diet usually beans and stiff maize porridge of poor quality and rarely well prepared. School canteens sell foods without regard to their nutritive value and hygienic regulations [13]. With the introduction of Universal Primary Education (UPE) in Uganda, many children have been able to attend school but little or no attention has been given to school feeding. The study, therefore, intended to assess the prevalence, dietary and health risk factors of nutritional anaemia amongst 11-14 year old girls attending primary schools in Masindi District of Western Uganda since they are vulnerable to anaemia.

\section{METHODS}

\section{Study design}

This cross-sectional study was conducted in Masindi, a rural district and one of the moderately developed districts in Uganda in July 2006. Masindi district is located in the Mid-western part of Uganda. The district is generally a plateau land with an altitude of 621 metres - 1158 metres above sea level [14]. Two schools, one urban and the other rural were selected basing on presence of girls schools in the district. These schools were UPE schools and under this system, the government meets all the school dues but it is the responsibility of parents to feed their children. A total of 109 girls (54 from the urban school and 55 from the rural school) aged 11-14 years were selected using simple random sampling. The sample size was determined using the formula $n=Z^{2} \mathrm{pq} / \mathrm{d}^{2}$ [15]. 


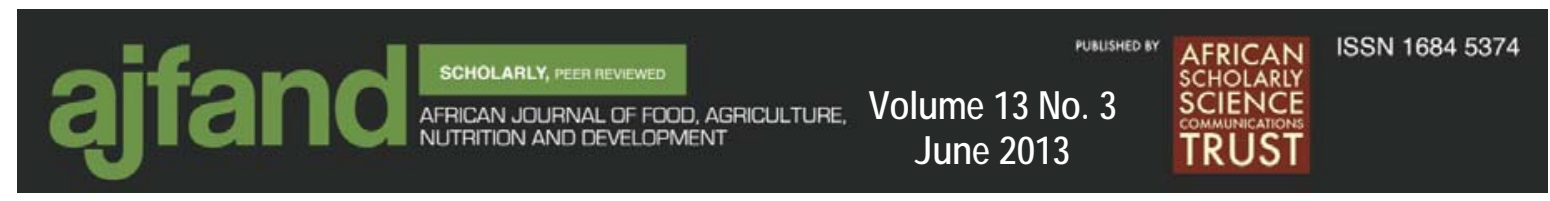

Hence according to the formula

$\mathrm{n}=\left(\frac{\left.1.96^{2} \times 0.077 \times 0.923\right)}{(0.05))^{2}}=109\right.$ subjects

$(0.05)^{2}$

Whereby

$\mathrm{n}=$ sample size required

$\mathrm{z}=(1.96)$. Confidence level test statistic at the desired level of significance

$\mathrm{p}=(7.7 \%)$. Proportion of variable of interest (anaemia prevalence amongst primary

school children in a similar study in Uganda) [6].

$\mathrm{q}=(1-\mathrm{p})$. Proportion of non anaemic children

$\mathrm{d}=$ acceptable error willing to be committed.

Students with sickle cell anaemia and those with a recent history of Tuberculosis (TB), Human Immunodeficiency Virus (HIV) and Urinary Tract Infections were excluded from the study. Ethical approval for the study was obtained from the Ugandan National Council of Science and Technology and parental consent and students' assent were obtained by signing a form.

\section{METHODOLOGY}

Interviews were conducted by trained enumerators to collect data on dietary and health risk factors of nutritional anaemia. Self administered questionnaires were piloted in a sample of similar aged children $(\mathrm{n}=10)$ in two schools of similar settings and required adjustments were made. Dietary assessment was performed using 24hour dietary recalls [16]. Information was collected on meals, food types/ mixed dishes, cooking methods and weight of each food/dish that each individual had consumed in the previous twenty-four hours. For each of the girls, three repeated twenty-four hour recalls were carried out for a month on non-consecutive days excluding weekends and the average individual nutrient intake was determined. Food models, photographs and common household measures were used to assist in recalling the portion size of the food. Twenty-four hour dietary recall data was analyzed using the East African Food Composition Table [17]. Malaria was self reported. The Lovibond comparator was used to assay Haemoglobin $(\mathrm{Hb})$ level in whole blood after conversion of $\mathrm{Hb}$ to oxyhaemoglobin by ammonia [18]. A high standard commercially prepared $\mathrm{Hb}$ standard $(18 \mathrm{~g} / \mathrm{dl})$ solution was used to check the high value in the machine; the readings obtained were within the range given for the $\mathrm{Hb}$ standard. A single whole blood sample was collected, by finger stick, from each of the consented girls by a trained laboratory technician. The first drop of blood was cleaned off and the second drop $(0.05 \mathrm{ml})$ was collected and mixed with 10 millilitres of $0.04 \%$ Ammonium solution using an automatic $50 \mu$ pipette. The solution was mixed until full colour development had taken place; then after about 5 minutes the results were compared with the standard disc in a Lovibond Comparator 2000+ (United Kingdom). Two readings were taken per sample by two independent laboratory technicians and the average was calculated. 


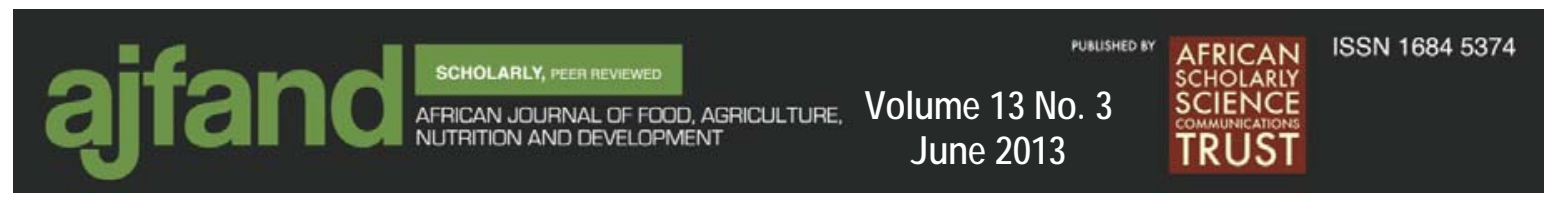

\section{Statistical analysis}

Data was analysed using SPSS for windows version 12.0 [19]. Descriptive statistics were performed and statistical significance was determined at $p<0.05$. Pearson's chisquare test was used to determine associations between anaemia and the diet and health risk factors whilst correlation analysis was performed using Pearson's correlation coefficient analysis. Nutrient intake as assessed by twenty-four hour recalls was recorded based on WHO recommendations [20]. Energy intake was not controlled for in the analysis. The severity and magnitude of anaemia among school girls living $\leq 1000$ metres above sea level was categorized as 'severe' $(\mathrm{Hb}<$ than 7.0 $\mathrm{g} / \mathrm{dl}$ ) 'moderate' ( $\mathrm{Hb}$ in the range $7.0-9.9 \mathrm{~g} / \mathrm{dl}$ ) 'mild' ( $\mathrm{Hb}$ in the range $10.0-11.9$ $\mathrm{g} / \mathrm{dl})$ and 'normal' $(\mathrm{Hb}>12 \mathrm{~g} / \mathrm{dl})[21]$.

\section{RESULTS}

There was a high prevalence $(45.9 \%)$ of mild to moderate anaemia among all the girls (Table 1$)$. There were more cases of mild $(37.6 \%)$ than moderate $(8.3 \%)$ anaemia and no cases of severe anaemia among all the girls. The prevalence of anaemia was significantly $(p=0.045)$ higher in the urban school where $61.1 \%$ of the girls were anaemic compared to $30.9 \%$ of the girls in the rural school.

\section{Dietary factors responsible for anaemia}

Table 2 shows that majority of the girls had three meals per day; there were more girls taking three meals per day in the rural than the urban school. Only girls in the boarding section were offered school meals and most girls especially in the rural school packed lunch. There was, however, no significant association between the number of meals and the haemoglobin level $(\mathrm{p}=0.8)$. Plant-based foods such as mangoes, beans, leafy vegetables and maize meal were the most consumed while animal foods were the least consumed. Taking tea with meals was not a common practice except when taking breakfast. As can be seen in Tables 3 and 4 majority of the girls in both schools had intakes of dietary fibre and vitamin $\mathrm{C}$ above the recommended amount; but more than half of the girls in the urban school had less than the recommended intake of iron, protein, folate, riboflavin and vitamin A. Energy intake was often lower than recommended in the rural than urban school. The majority of girls with inadequate intake of iron, vitamin $\mathrm{A}$, folate, riboflavin, protein and energy were anaemic and this was significant at $\mathrm{p} \leq 0.001$.

Figure 1 illustrates that stomach ache and malaria were the most reported incidences and de-worming was the most common health behaviour among the girls in each school. 


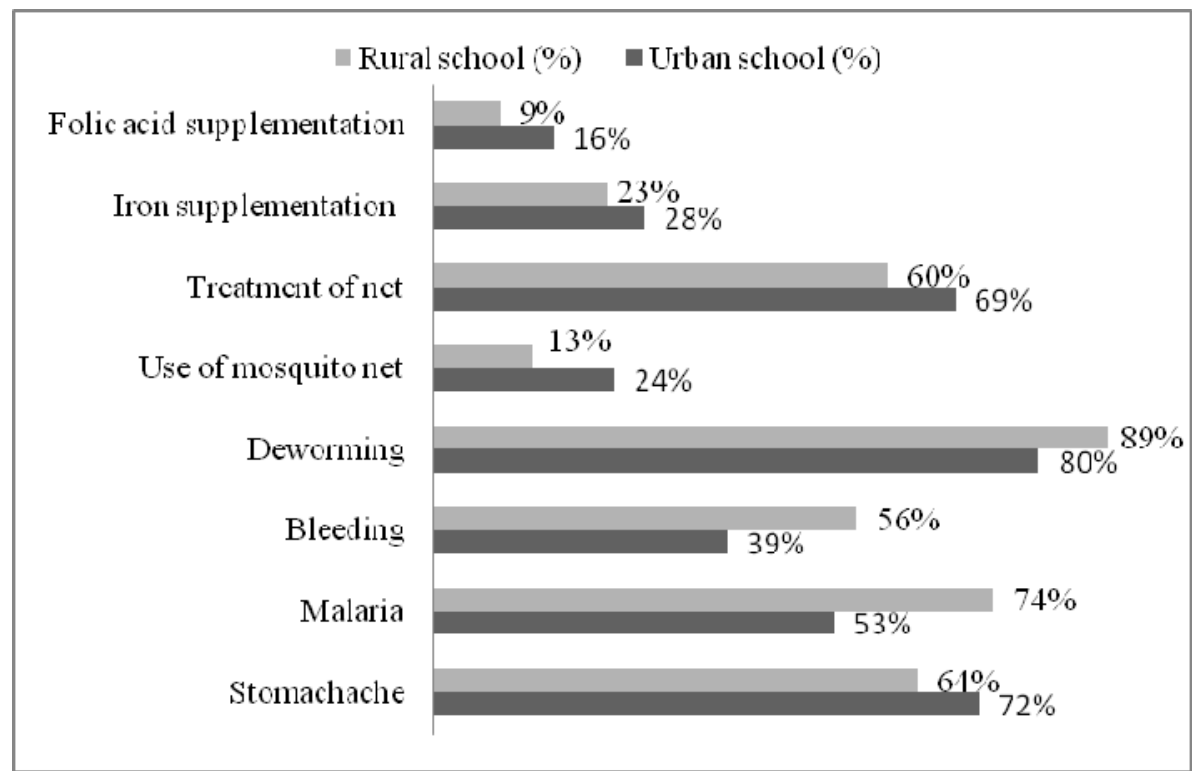

Figure 1: Illnesses and health behaviour of girls in rural and urban schools

There were no significant associations between anaemia and these health indices ( $>0.09$ ). De-worming in the urban school was performed by teachers within the school setting whereas in the rural school it was performed by nurses in a clinic attached to the school. There were significantly more anaemic girls among those dewormed by teachers than nurses $(\mathrm{p}=0.001)$.

Pearson's correlation coefficient analysis showed that anaemia was positively correlated with incidence of malaria $(\mathrm{r}=0.54, \mathrm{p}=0.02)$, stomach ache $(\mathrm{r}=0.31, \mathrm{p}=$ $0.03)$, onset of menstruation $(\mathrm{r}=0.24, \mathrm{p}=0.04)$, improper de-worming $(\mathrm{r}=0.51, \mathrm{p}=$ $0.04)$ and inadequate dietary intake $(r=0.61, \mathrm{p}<0.001)$.

\section{DISCUSSION}

\section{Prevalence of anaemia among the school girls}

The data indicates high prevalence of anaemia among all the girls. This is similar to findings observed from other studies amongst school children in Tanzania [22] and Sri Lanka [23]. It is, however, different from the 1993 reports among primary school children in Masindi district, which may be because of the clinical assessment methods used in the study [6]. The prevalence of anaemia was higher among the girls in the urban school compared to the rural school. This is different from previous reports where anaemia was most common in rural than urban communities $[5,24]$. The prevalence of moderate and mild anaemia among this cohort is comparable to the reported prevalence levels in adolescents girls aged 15-19 years in Uganda where $0.3 \%$ had severe anaemia, $10.0 \%$ moderate and $33.1 \%$ mild anaemia [5]. As with most institution-based studies, there were no cases of severe anaemia in this study. 


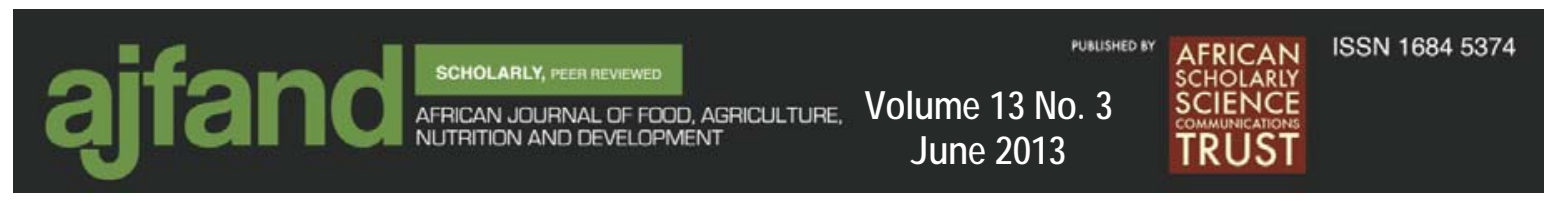

Severe anaemia cases are highly unlikely in school-based studies due to the health worker effect (biases that result from selection effects in occupational cohorts) [25]. However, even mild to moderate anaemia affects wellbeing, resulting in fatigue, stress and decreased work capacity [9].

\section{Dietary risk factors for anaemia}

Though majority of the girls had three meals per day, this did not significantly contribute to reduction in anaemia because the meals were quantitatively and qualitatively inadequate, mostly composed of a mixture of overcooked leafy vegetables and beans with either maize meal as the staple or cassava. These findings compare well with reports where school meals in Uganda were nutritionally inadequate [13]. There were no girls taking school meals in the rural school because the school was purely a day school and this compares well with findings where most day schools lacked an organized feeding programme [12]. Majority of urban school girls had diets deficient in iron, folate, riboflavin and vitamin A compared to the rural school girls because their meals were more quantitatively inadequate but their meal compositions were not so different. Vitamin $\mathrm{C}$ intake was high this may be due to the consumption of leafy vegetables and mangoes which were in season at the time of this study. The meals were all bulky with a lot of fibre but unlike the rural girls, the urban girls had more energy intake from sugary drinks like quencher, jolly jars, supper dip which were basically composed of calories.

Inadequate intake of iron, protein, folate, riboflavin, vitamin A and energy contributed significantly to anaemia $(\mathrm{p} \leq 0.001)$; this findings support the Uganda demographic and health survey report of 2006 that anaemia in Uganda was mainly due to iron deficiency [5]. Inadequate iron and protein intake may negatively influence haemoglobin production [11]. Folate deficiency exacerbates the anaemic state as it can lead to both megaloblastic and folate deficiency anaemia [11]. Riboflavin deficiency can contribute to anaemia by impairing iron mobilization, reducing the synthesis of haemoglobin and iron absorption while vitamin A protects against anaemia through the enhancement of growth and differentiation of erythrocyte progenitor cells, modulation of immunity to infectious disease and mobilization of iron stores from the tissues [10]. Low levels of energy foods can also exacerbate the anaemic state [11]. Much intake of fibre contributed significantly to anaemia in the study girls $(p=0.02)$. Fibre was mostly from cereal foods and these have a high content of phytic acid, a significant inhibitor of dietary iron [26]. Complete exclusion of animal foods from girls' meals could lead to vitamin $\mathrm{B}_{12}$ deficiency which is likely to result in megaloblastic anaemia, further affecting haemoglobin levels [11].

\section{Health risk factors for anaemia}

Malaria cases were many because of the season coupled with less use of mosquito nets. De-worming was common health behaviour in schools because of the Ugandan policy to de-worm all school children (5-14 years) but due to lack of medical supplies, de-worming programs in schools are not fully implemented in Uganda [5]. Administration of de- worming tablets by nurses rather than teachers had a significant effect on the anaemic status of the girls because of improved compliance and 


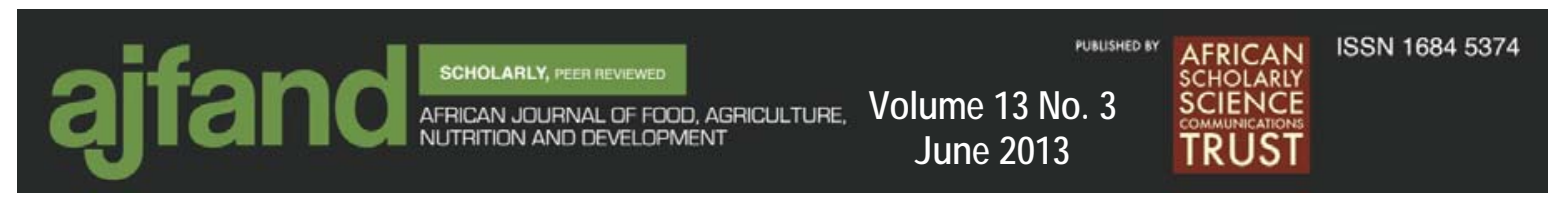

effectiveness of the drug via the delivery of the correct prescriptions [4]. The number of girls taking iron and folic acid supplements was low. This is because supplementation policies have not yet been implemented in schools in Uganda [7]. There was, however, no significant association between malaria incidences and anaemia perhaps because of the method used for data collection.

Anaemia was positively correlated with malaria, stomach ache, improper de-worming and inadequate dietary intake. Infections lower haemoglobin levels [4]. Malaria leads to increased red blood cell destruction combined with suppression of erythropoiesis (development of red blood cells) [27]. Malaria may cause loss of functional body iron stores through immobilization in the form of hemaizon (malaria pigments) and urinary excretion of iron thus decreasing iron stores and potentially inducing iron deficiency [28]. Worms can be a significant cause of anaemia particularly in school children with increased iron requirements as they can reduce appetite and nutrient absorption through diarrhea [4]. The menstrual cycle can also reduce haemoglobin levels significantly.

The major limitations of this study include the following: Difficult to get a nutritional program that would determine the nutrient content of vitamin $\mathrm{B}_{12}$, zinc, copper and cobalt in the diets; they were of interest to the study because of their association with anaemia: Using the 1987 East African Food Composition Table [17]. The present food composition table is over 25 years old and therefore needs urgent review.

\section{CONCLUSION}

There was a high prevalence of anaemia in school girls aged 11-14 years residing in Masindi District of Western Uganda, particularly amongst girls attending the urban school. Inadequate intake of iron, protein, folate, riboflavin, vitamin A and energy and excess intake of dietary fibre contributed significantly to anaemia. Prevalence of malaria cases was high and although de-worming has been implemented in schools, it was not yet effectively done. There is an urgent need for a national anaemia assessment within this age group in Uganda. There is also a need to strengthen the School Health Program that utilises the guidelines of the Uganda Anaemia Policy for school age children. These include nutrition education, encouraging use of treated mosquito nets, regular and proper administration of de-worming tablets, hygiene and sanitation.

\section{ACKNOWLEDGEMENTS}

The authors would like to acknowledge the support given by the management and staff of both the urban and the rural schools during data collection. Gratitude also goes to Mr. Harrison Tusabe, the laboratory technician of Masindi hospital for the laboratory work he performed for this study. 


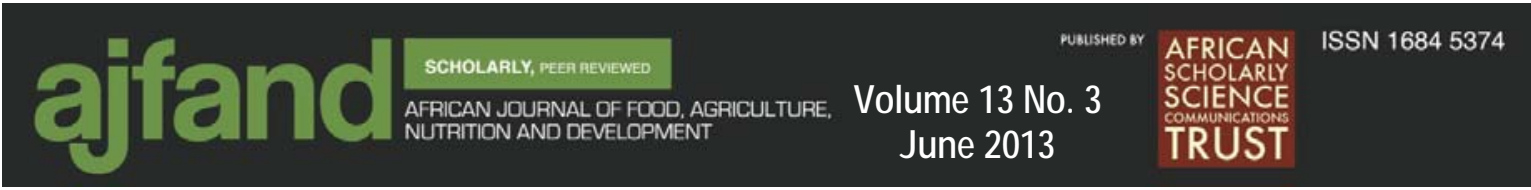

Table 1: Prevalence of Anaemia among the girls in the urban and rural schools

\begin{tabular}{|c|c|c|c|c|c|c|}
\hline \multirow[t]{2}{*}{ Anaemia status } & \multicolumn{2}{|c|}{$\frac{\text { Urban school }}{(N=54)}$} & \multicolumn{2}{|c|}{$\frac{\text { Rural school }}{(\mathrm{N}=55)}$} & \multicolumn{2}{|c|}{$\frac{\text { Total }}{(\mathrm{N}=109)}$} \\
\hline & $\mathrm{n}$ & $\%$ & $\mathrm{n}$ & $\%$ & $\mathrm{n}$ & $\%$ \\
\hline Severe & 0 & 0 & 0 & 0 & 0 & 0 \\
\hline Moderate & 7 & 13.0 & 2 & 3.6 & 9 & 8.3 \\
\hline Mild & 26 & 48.1 & 15 & 27.3 & 41 & 37.6 \\
\hline Normal & 21 & 38.9 & 38 & 69.1 & 59 & 54.1 \\
\hline $\begin{array}{l}\text { Total no of girls with } \\
\text { anaemia }\end{array}$ & 33 & 61.1 & 17 & 30.9 & 50 & 45.9 \\
\hline
\end{tabular}

Table 2: Meal patterns of the girls

\begin{tabular}{lcc}
\hline Dietary factor & $\frac{\text { Urban school }}{\%}$ & $\frac{\text { Rural school }}{\%}$ \\
\hline Number of meals per day & 17 & 9 \\
2 meals & 76 & 86 \\
3 meals & 7 & 5 \\
4 meals & & \\
Source of lunch & 11 & 0 \\
School meals & 26 & 13 \\
Home & 4 & 2 \\
School canteen & 51 & 76 \\
Packed lunch & 8 & 9 \\
None & & \\
\hline
\end{tabular}

Table 3: Macronutrient intake of the girls assessed by 24- hour recall

\begin{tabular}{lcccccc}
\hline & \multicolumn{2}{c}{ Urban school } & \multicolumn{2}{c}{ Rural school } & \multicolumn{2}{c}{ Total } \\
& \% & Mean+SD & \% & Mean +SD & (n) & (\%) \\
\hline $\begin{array}{l}\text { Protein (41g)* } \\
\text { \% below recommended }\end{array}$ & 55.6 & $27.1 \pm 10.4$ & 36.4 & $30.7 \pm 9.6$ & 50 & 45.9 \\
\% above recommended & 44.4 & $58.0 \pm 15.3$ & 63.6 & $65.3 \pm 14.7$ & 59 & 54.1 \\
$\begin{array}{l}\text { Energy (1845kcalories)* } \\
\text { \% below recommended }\end{array}$ & 78.8 & $1463.6 \pm 421.6$ & 54.7 & $1803.7 \pm 340.5$ & 73 & 66.7 \\
\% above recommended & 21.2 & $2509.1 \pm 318.8$ & 45.3 & $2854.5 \pm 528.7$ & 36 & 33.3 \\
$\begin{array}{l}\text { Dietary fibre (30g) } \\
\text { \% below recommended }\end{array}$ & 27.8 & $22.4 \pm 4.5$ & 03.6 & $26.3 \pm 5.6$ & 17 & 15.6 \\
\% above recommended & 72.2 & $52.5 \pm 14.1$ & 96.4 & $57.4 \pm 17.8$ & 92 & 84.4 \\
\hline
\end{tabular}

* Reference: WHO, Dietary Reference Intake values [20] 


ajfand

Table 4: Micronutrient intake of the girls assessed by 24- hour recall

\begin{tabular}{|c|c|c|c|c|c|c|}
\hline \multirow[t]{2}{*}{ Nutrient } & \multicolumn{2}{|c|}{ Urban school } & \multicolumn{2}{|c|}{ Rural school } & \multicolumn{2}{|c|}{ Total } \\
\hline & $\%$ & Mean + SD & $\%$ & Mean & (n) & $(\%)$ \\
\hline \multicolumn{7}{|l|}{ Iron (15mg) } \\
\hline$\%$ below recommended & 70.4 & $9.1 \pm 2.6$ & 30.9 & $11.7 \pm 2.5$ & 55 & 50.5 \\
\hline$\%$ above recommended & 39.6 & $18.6 \pm 4.9$ & 69.1 & $20.4 \pm 4.7$ & 54 & 49.5 \\
\hline \multicolumn{7}{|l|}{ Folate (200 ug) } \\
\hline$\%$ below recommended & 87.0 & $104.4 \pm 29.8$ & 58.2 & $120.7 \pm 15.7$ & 79 & 72.5 \\
\hline$\%$ above recommended & 13.0 & $184.0 \pm 29.2$ & 41.8 & $205.3 \pm 15.7$ & 30 & 27.5 \\
\hline \multicolumn{7}{|l|}{ Riboflavin (1.1mg) } \\
\hline$\%$ below recommended & 75.9 & $0.9 \pm 1.0$ & 60.0 & $0.9 \pm 0.2$ & 55 & 50.5 \\
\hline$\%$ above recommended & 24.1 & $1.5+0.2$ & 40.0 & $1.5+0.3$ & 54 & 49.5 \\
\hline \multicolumn{7}{|l|}{ Vitamin C (35mg) } \\
\hline$\%$ below recommended & 24.1 & $28.78 \pm 10.8$ & 12.7 & $32.9 \pm 10.8$ & 20 & 18.3 \\
\hline$\%$ above recommended & 75.9 & $183.53 \pm 81.5$ & 87.3 & $244.0 \pm 144.8$ & 89 & 81.7 \\
\hline \multicolumn{7}{|l|}{ Vitamin A (600 $\mu g)$} \\
\hline$\%$ below recommended & 59.3 & $465.0 \pm 229.9$ & 29.1 & $532.8 \pm 187.4$ & 48 & 44.0 \\
\hline$\%$ above recommended & 40.7 & $1248.4 \pm 498.1$ & 70.9 & $2120.3 \pm 489.1$ & 61 & 56.0 \\
\hline
\end{tabular}

*Reference: WHO, Dietary Reference Intake values [20]

Table 5: Distribution of all the girls by anaemia status and macronutrient intake

\begin{tabular}{lccc}
\hline \multicolumn{1}{c}{ Nutrient } & $\begin{array}{lccc}\text { Anaemia } \\
\text { Protein (419*) }\end{array}$ & $\frac{\text { Normal }}{\mathbf{\%}}$ & p values \\
\hline $\begin{array}{l}\text { \% below recommended } \\
\text { \% above recommended }\end{array}$ & 74.2 & 23.7 & $\mathbf{p}<\mathbf{0 . 0 0 1}$ \\
$\begin{array}{l}\text { Dietary fibre (30g*) } \\
\text { \% below recommended }\end{array}$ & 25.8 & 76.3 & \\
\% above recommended & 24.5 & 93.2 & $\mathbf{p}=\mathbf{0 . 0 2 1}$ \\
$\begin{array}{l}\text { Energy (1845*) } \\
\text { \% below recommended }\end{array}$ & 75.5 & 6.8 & \\
\% above recommended & 88.2 & 48.2 & $\mathbf{p}<\mathbf{0 . 0 0 1}$ \\
\hline
\end{tabular}

* Reference: WHO, Dietary Reference Intake values [20] 


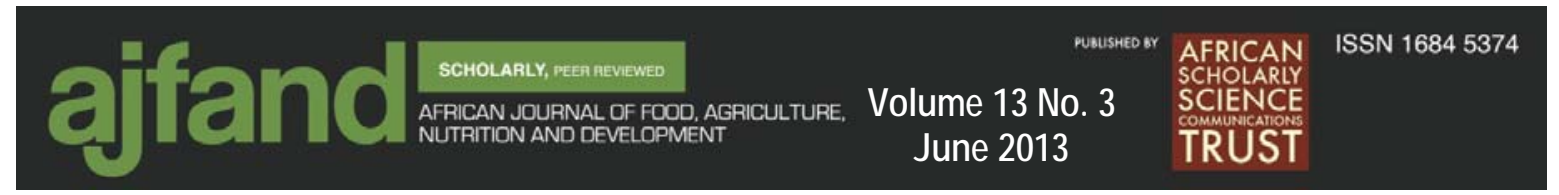

Table 6: Distribution of all the girls by anaemia status and micronutrient intake

\begin{tabular}{|c|c|c|c|}
\hline Nutrient & $\begin{array}{c}\text { Anaemia } \\
\%\end{array}$ & $\begin{array}{c}\text { Normal } \\
\%\end{array}$ & p values \\
\hline \multicolumn{4}{|l|}{ Iron (15 mg*) } \\
\hline$\%$ below recommended & 82.3 & 27.1 & $\mathrm{p}<0.001$ \\
\hline$\%$ above recommended & 17.7 & 72.9 & \\
\hline \multicolumn{4}{|l|}{ Vitamin A $\left(600 \mu g^{*}\right)$} \\
\hline$\%$ below recommended & 58.3 & 30.5 & $\mathrm{p}=0.001$ \\
\hline$\%$ above recommended & 41.7 & 69.5 & \\
\hline \multicolumn{4}{|l|}{ Folate (200 $\left.\mu \mathrm{g}^{*}\right)$} \\
\hline$\%$ above recommended & 3.7 & 54.2 & \\
\hline \multicolumn{4}{|l|}{ Riboflavin (1.1mg*) } \\
\hline$\%$ below recommended & 93.9 & 49.2 & $\mathrm{p}<0.001$ \\
\hline$\%$ above recommended & 6.1 & 50.8 & \\
\hline \multicolumn{4}{|l|}{ Vitamin C (35 mg*) } \\
\hline$\%$ below recommended & 31.9 & 13.6 & $\mathrm{p}=0.081$ \\
\hline$\%$ above recommended & 68.1 & 86.4 & \\
\hline
\end{tabular}




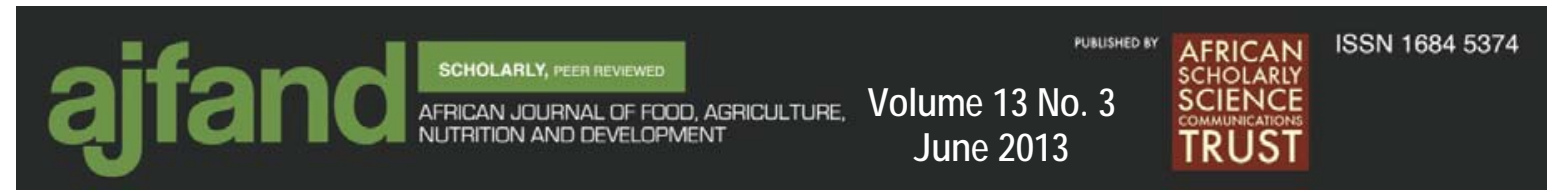

\section{REFERENCES}

1. Kraemer $\mathbf{K}$ and $\mathbf{M}$ Zimmerman Nutritional anaemia. Zurich, Switzerland: Sight \& Life Press, 2007.

2. Jamison D, Breman J, Measham A, Alleyne G, Claeson M, Evans D, Jha $\mathbf{P}$, Mills $\mathbf{A}$ and $\mathbf{P}$ Musgrove Disease Control Priorities in Developing Countries, $2^{\text {nd }}$ ed., New York: Oxford University Press, 2006.

3. ACC/SCN. Fourth Report on the World Nutrition Situation: nutrition throughout the life cycle, Geneva: ACC/SCN in collaboration with IFPRI, 2000 .

4. Sandra LH, Zehner MP, Harvey P, Luann MA, Piwoz E, Samba KN, Combest C, Mwadime R and V Quinn Essential Health Sector Actions to Improve Maternal Nutrition in Africa: regional centre for quality of health care at Makerere University in Uganda and linkages, Washington DC: Academy for Educational Development, 2001.

5. Uganda Bureau of Statistics (UBOS) and Macro International Uganda Demographic and Health Survey 2006, Calverton: UBOS and Macro International Inc., 2007.

6. Ministry of Health The National Rapid Assessment Nutrition Survey in Uganda: district reports, Nutritional Department: Ministry of Health, 1993.

7. Ministry of Health National Anaemia Policy, Ministry of Health: Uganda, 2002.

8. Massawe SN, Ronquist G, Nystrom L and G Lindmark Iron status and Iron deficiency anaemia in adolescents in a Tanzanian sub/urban area. Gynecol. Obstet. Invest 2002; 54:137-144.

9. Majid E Selected Major Risk Factors and Global and Regional Disease. The Lancet, 2002; 360: 1347-1360.

10. Fishman SM, Christine $\mathbf{P}$ and KP West The role of Vitamins in the Prevention and Control of Anaemia, Pub. Health Nutr. 2000; 3:125-150.

11. Lake B and M Waterworth Food and Nutrition. London: Bell and Hyman Ltd 1980.

12. Jitta J, Kyaddondo D and E Owino Preliminary review of the health of school age children in Uganda. Phase 1: A Document Review, 1996.

13. Bachou $\mathbf{H}$ The nutrition situation in Uganda, South African Journal of Clinical Nutrition 2000; 13:3-5. 
14. Masindi District Directorate of Health Services Masindi District Health services Annual Report, 2007.

15. Bryan FJ The Design and Analysis of Research Studies, University of Otago: Uk, Cambridge University Press, 1992.

16. Gibson RS Reproducibility in Dietary Assessment: principles of nutritional assessment, New York: Oxford University Press, 2005.

17. West CE, Pepping F, Scholte I and W Jansen Food Composition Table for Energy and Eight Important Nutrients in Foods Commonly Eaten in East Africa, HFF Albers Technical Centre for Agriculture and Rural Cooperation (CTA) of ACP $\backslash E C P$ Convention of Lome, and Food and Nutrition Cooperation (ECSA), 1987.

18. Carter $\mathbf{J}$ and $\mathbf{O}$ Lema Practical Laboratory Manual for Health workers in Eastern Africa, Nairobi: African Medical and Research Foundation, 2003.

19. Statistical Programme for Social Scientists SPSS Base Version 12 for Windows User's guide, Chicago: SPSS Inc, 2003.

20. World Health Organisation Population Dietary Recommendation for Minerals and Vitamins, Total carbohydrates, Proteins and Fats (Principles of Nutritional Assessment. National Centre for Health Statistics, USA, 2003.

21. World Health Organisation Haemoglobin concentrations for the diagnosis of anaemia and assessment of severity. Vitamin and Mineral Nutrition Information System. Geneva, World Health Organisation, 2011.

22. Lwambo $\mathbf{N}$ Age Patterns in Stunting and Anaemia in African School Children: a cross sectional study in Tanzania. Eur. J. Clin. Nutr. 2000; 54:3640.

23. Fornando SD, Parana VSR, Rajakaruna J, Werrasinghe S, Silva D and AR Wickermansinghe The Health and Nutritional status of School Children in two Rural Communities in Sri-lanka. Trop. J. Med. and Intern. Health 2000; 5: 450 - 452.

24. Galloway R Anaemia Prevention and Control: What works? Part 1 Program guidance. Population, Health and Nutrition Information -Washington DC, 2003.

25. Verma A, Rawal VS, Kedia G, Kumar D and J Chauhan Factors influencing anaemia among Girls of School Age (6-18 years) from the Slums of Ahmadabad city. Ind. J. Community Med. 2004; 29: 25-26. 


ajfand

26. Gillooly M, Bothwell TH, Torrance JD, MacPhail AP, Derman DP, Bezwoda WR, Mills W, Charlton RW and F Mayet The Effects of Organic Acid, Phytates and Polyphenols on the Absorption of Iron from Vegetables, Brit. J. Nutr.1983; 49:331-342.

27. Crawley $\mathbf{J}$ Reducing the Burden of Anaemia in Infants and Young Children in Malaria Endemic Countries of Africa: from evidence to action, Am. J. Trop. Med and Hyg. 2004; 71:25-34.

28. Brabin BJ The Role of Malaria in Nutritional Anaemia. New York: Raven Press, 1992. 